\title{
Performance evaluation of unmodified and thermally modified Iyi-Nsukka kaolinite clay as heterogeneous catalyst for biodiesel production.
}

\author{
${ }^{1}$ Odenigbo J.O., ${ }^{2}$ Chime T.O., ${ }^{2}$ Egbuna S.O. \\ ${ }^{1}$ Department of Engineering Research Development and Production, Projects Development Institute (PRODA) Enugu, P.M.B.1609 Enugu, Nigeria. \\ ${ }^{2}$ Department of Chemical Engineering, Enugu State University of Science and Technology, P.M.B.01660 Enugu, Enugu state, Nigeria.
}

DOI: 10.29322/IJSRP.11.07.2021.p11590

http://dx.doi.org/10.29322/IJSRP.11.07.2021.p11590

\begin{abstract}
The unmodified Iyi-Nsukka kaolinite clay catalyst (UMIKKCat) and thermally modified Iyi-Nsukka kaolinite clay catalyst (TMIKCCat800) were prepared and characterised using X-ray diffraction (XRD), Fourier transform infrared spectroscopy (FTIR), Scanning electron microscopy (SEM) and Atomic abrasion spectrophotometry (AAS) to verify catalyst properties. Gmelina seed oil was extracted using Soxhlet extraction method utilising n-hexane as solvent. The percentage oil extracted from gmelina seed was $50 \%$, proven its viability as feedstock for biodiesel production. The extracted lipid was characterised to determine the fatty acid profile using Gas chromatography/ mass spectroscopy (GC/MS) Shimadzu, Japan. The methyl ester produced by transesterification of gmelina seed oil with both catalysts were within acceptable limits of ASTM Standard. Central composite design (CCD) was applied and was found adequate in predicting and optimizing the biodiesel production. The optimal process parameters include: reaction time 3 hours, catalyst concentration $3 \mathrm{wt}$. percent, methanol/oil ratio 12:1, reaction temperature $60{ }^{\circ} \mathrm{C}$ and agitation speed 300rpm with biodiesel yield of $84.5 \%$ and $96.4 \%$ respectively for unmodified Iyi-Nsukka kaolinite clay catalyst (UMIKCCat) and thermally modified Iyi-Nsukka kaolinite clay catalyst (TMIKCCat800). It was observed that thermal modification lead to transformation of the kaolin to meta-kaolinite, increase surface area and porosity of the clay catalyst.
\end{abstract}

Index Terms- Iyi-Nsukka kaolin clay, thermal modification, transesterification, gmelina seed oil

\section{INTRODUCTION}

$\mathrm{O}$ ver the years, world energy crisis and increase in global warming led researchers to focus in development of renewable, sustainable, green and ecological friendly energy (Demirbas, 2009). Biodiesel fuel has shown great promise as an alternative to petro-diesel fuel. Biodiesel can be defined as fatty acid alkyl esters derived from the trans-esterification of triglycerides (vegetable oils or animal fats) with alcohol (methanol, ethanol, propanol and butanol). Although there are at least four ways in which oils and fats can be converted to biodiesel namely: pyrolysis (thermal cracking), micro-emulsification, dilution and trans-esterification (Demirbas, 2009; Singh, 2010).
Among these methods, trans-esterification is the best method for producing higher quality biodiesel (Singh, 2010).

Biodiesel production is widely conducted through transesterification reaction, catalyzed by homogeneous catalysts or heterogeneous catalysts. The most notable catalyst used in producing biodiesel is the homogeneous alkaline catalyst such as $\mathrm{NaOH}, \mathrm{KOH}, \mathrm{CH}_{3} \mathrm{ONa}$ and $\mathrm{CH}_{3} \mathrm{OK}$. The choice of these catalysts is due to their higher kinetic reaction rates. However, due to high cost of refined feedstocks and difficulties associated with use of homogeneous alkaline catalysts to transesterify low quality feedstocks for biodiesel production, development of various heterogeneous catalysts are now on the increase. Development of heterogeneous catalyst such as modified clay catalysts can overcome most of the problems associated with homogeneous catalysts due to its thermal stability and easy seperability.

Kaolin is a fine clay mineral. Its major constituent is kaolinite $\left(\mathrm{Al}_{2} \mathrm{O}_{3} \cdot 2 \mathrm{SiO}_{2} \cdot 2 \mathrm{H}_{2} \mathrm{O}\right)$, a hydrous aluminum silicate with a single silica tetrahedral layer linked through oxygen atoms to a single alumina octahedral layer. The common minerals occurring with kaolin include parent rocks like feldspar and mica, quartz, ferruginous, titanoferrous, and carbonaceous materials (Scorzelli, 2008). Kaolin is mostly used in porcelain, nuclear waste treatment pottery, paper, pigments and filler manufacturing (Hosseini, 2007). It equally used as adsorbent and catalysts (Lenarda, 2007; Atta, 2007; Lussier, 2007). Therefore this study evaluate the performance of unmodified and thermally modified Iyi-Nsukka kaolinite clay as heterogeneous catalyst for biodiesel production

\section{EXPERIMENTAL}

Catalysts preparation- collected clay samples were dried using laboratory hot air oven (Model: DHG-9101-ISA, England) at $150{ }^{\circ} \mathrm{C}$ for 6 hours to remove moisture. The samples were pulverized using ball mill and sieved using mechanical sieve machine (manufactured by CISA) with sieve size $250 \mu \mathrm{m}$. Thermal modification was done by activating the clay at $800^{\circ} \mathrm{C}$ for 4 hours using laboratory muffle furnace (manufactured by Carbolite).

Catalysts characterisation was done using an EMPYREAN x-ray diffractometer manufactured by PA analytical, operating at generator voltage: $45 \mathrm{kv}$, tube current: $40 \mathrm{~mA}$ and measurement temperature: $25^{\circ} \mathrm{C}$. The Fourier transform infrared spectra (FTIR) of the kaolin clay catalysts samples were done by the use of the 
FTIR spectrophotometer using transmittance method with range 4000 - 650 wavenumber $\left(\mathrm{cm}^{-1}\right)$ to show the functional group present in these catalysts samples. Scanning electron microscope (SEM) of the kaolin clay catalysts samples were done using Scanning electron microscope (SEM) model: Phenom ProX, manufactured by Eindhoven, Netherland to show the morphology of the catalysts. Atomic absorption spectrophotometry (AAS) of clay catalysts were done using Atomic absorption spectrophotometer 210VGP, manufactured by Buck Scientific, England. Oil extraction was done by soxhlet extraction and characterised using Gas chromatography mass spectra GC-MS manufactured by Shimadzu, Japan, Model number GCMSQP2010 PLUS.

Design of experiment was done using Central composite design (CCD) to determine the optimum values of the process variables. The fractional factorial design was used to obtain a quadratic model, consisting of factorial trials to estimate quadratic effects. To examine the combined effect of the five different factors (independent variables); catalyst concentration, methanol/oil molar ratio, reaction temperature, reaction time and agitation speed, on biodiesel yield and derive a model, a two-levelfive - factor $\left(2^{5-1}+2 * 5+6\right)$ Central composite response design $=32$ experiments were performed. The matrix for the five variables was varied at two levels $(-1$ and +1$)$. The lower level of variable was designated as " -1 " and higher level as " +1 ". The experiments were performed in random order to avoid systematic error. Design expert 11.0. was used. The response was expressed as \% yield of biodiesel $(\mathrm{Y})$, calculated as $\left\{\left(V_{2}\right) / \mathrm{V}_{1}\right\} \times 100$ where $\mathrm{V}_{1}$ is the initial volume of oil and $\mathrm{V}_{2}$ is the volume of biodiesel produced.

Transesterification- Appropriate quantity of prepared catalysts (3wt.\% of oil) and methanol/oil molar ratio (12:1) was weighed into $500 \mathrm{ml}$ three neck round bottom flask. The catalyst was allowed to dissolve in the methanol using magnetic stirring nob. The central opening of the flask was equipped with reflux condenser, one of the side opening was equipped with mercuryin-glass thermometer. The third aperture was closed with plastic stopper after introducing of all reactants constituents in the flask. For each of the experiment, catalyst concentration, temperature, reaction time, methanol/oil molar ratio and agitation speed were maintained as required in the experimental run matrix. When transesterification is completed, the products separated and dried by evaporation to remove water molecules.

\section{RESUlTS AND DisCUSSION}

X-ray Diffraction (XRD) of unmodified and thermally modified Iyi-Nsukka kaolin clay catalysts are presented in Figure 1 and 2. The XRD revealed that visible compounds present in unmodified Iyi-Nsukka clay catalyst (UMIKCCat) include: Quartz and kaolinite representing $56 \%$ and $44 \%$ with displacements: 0.000 and $0.000[\AA]$ at $\left[{ }^{\circ} 2 \mathrm{Th}\right]$ and chemical formulas: $\mathrm{Al}_{2} \mathrm{Si}_{2} . \mathrm{O}_{9}$ and $\mathrm{Si}_{3} . \mathrm{O}_{6}$ respectively. While the visible compounds in thermally modified Iyi-Nsukka kaolin clay catalyst (TMIKCCat800) include: Quartz, kaolinite and hematite, with

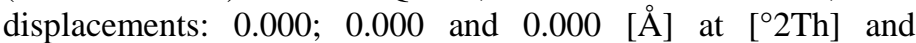

chemical formula: $\mathrm{Si}_{3} \mathrm{O}_{6} ; \mathrm{Al}_{2} \mathrm{Si}_{2} \mathrm{O}_{9}$ and $\mathrm{Fe}_{12} \cdot \mathrm{O}_{18}$, respectively. As a result of the thermal modification, hematite became present while alumina content and percentage weight decreased. This observation is in line with the findings of Panda et al. (2010).

Fourier transform infrared spectra (FTIR) of unmodified and thermally modified Iyi-Nsukka kaolin clay catalysts are presented in the Figure 3 and Figure 4 . The band region $3690.1 \mathrm{~cm}^{-1}$ was assigned to Al- - - O- H stretching surface hydroxyls, band region $1636.3 \mathrm{~cm}^{-1}$ was ascribed to $\mathrm{H}-\mathrm{O}-\mathrm{H}$ bending possibly absorbed water. The region $1114.5 \mathrm{~cm}^{-1}$ indicates the presence of Si-O stretching, the region 782.7 and $749.2 \mathrm{~cm}^{-1}$ were ascribed to $\mathrm{OH}$ deformation linked to $\mathrm{Al}^{3-}$ whereas the band region $678.4 \mathrm{~cm}^{-1}$ shows the presence of $\mathrm{Si}$ - quartz. The band region $909.5 \mathrm{~cm}^{-1}$ was ascribed to $\mathrm{OH}$ deformation, while the region $998.9 \mathrm{~cm}^{-1}$ represents Si-O quartz. This observation is in line with the findings of Diko, et al (2016), Panda et al. (2010) and Park et al., (2007). While the FTIR of thermally modified Iyi-Nsukka kaolin clay catalyst revealed that the band at $1043.7 \mathrm{~cm}^{-1}$ was assigned to $\mathrm{Si}-\mathrm{O}$ stretching, possibly due to hematite interference; $775.3 \mathrm{~cm}^{-1}$ represents $\mathrm{OH}$ deformation whereas the band at 682.7 was ascribed to $\mathrm{Si}-\mathrm{O}$ quartz. It was also noted that thermal modification led to the abstraction of the band at 3690.1 and $3623 \mathrm{~cm}^{-1}$ representing $\mathrm{Al}$ - - - O-H stretching surface hydroxyls, when compared to the unmodified Iyi-Nsukka kaolin clay catalyst. The band at 3365.8 representing $\mathrm{H}-\mathrm{O}-\mathrm{H}$ stretching showing absorbed water was removed by thermal modification at temperature of $800^{\circ} \mathrm{C}$ due to dehydroxylation which took place with loss of water.

The SEM micrograph of unmodified and thermally modified Iyi-Nsukka kaolin clay catalysts are presented in Figure 5 and Figure 6. The micrograph of thermally modified kaolin clay catalyst show more disaggregation and disintegrations of structure of the particles of the clay sheet upon thermal modification at $800^{\circ} \mathrm{C}$. The micrograph indicate more porous surfaces as shown in Figure 6, when compared to unmodified Iyi-Nsukka kaolin clay catalyst (Figure 5) in which the SEM micrograph shows agglomeration of particles, interlocking and interpenetration of kaolinite particles with aggregate arrangement. The result is in line with the findings of Panda et al. (2010) and Park et al. (2007). Elemental composition of the clay catalyst were determined by atomic absorption spectrophotometry. Values were reported in (\%) as shown in table 1 . The result shows that the dominant elements are $\mathrm{Al}_{2} \mathrm{O}_{3}$ and $\mathrm{SiO}_{2}$. The results were similar to the findings of Panda et al. (2010) and Park et al. (2007).

The percentage of oil extracted from the gmelina is $50 \%$. The relatively high oil content of gmelina seed oil shows its viability as feedstock for biodiesel production. The physiochemical properties of gmelina seed oil is presented in Table 3. It was observed that the free fatty acid, iodine value, peroxide value, saponification value of gmelina seed oil fall within the range for biodiesel production. The fatty acid profile of gmelina seed oil is presented in Figure 7, the result shows that stearic acid methyl ester is the dominant methyl ester $(40.08 \%)$, octadecanoic acid methyl ester (36.64\%), oleic acid (6.31\%), pentadecanoic acid methyl ester (5.18\%), archidic acid methyl ester $(1.49 \%)$ and palmitic acid $(0.77 \%)$. The observation is similar to the findings of Carrero, et al. (2011). 


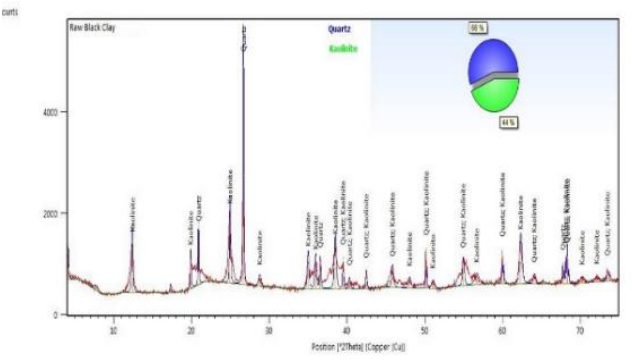

Fig.1: XRD of unmodified Iyi-Nsukka kaolin clay catalyst

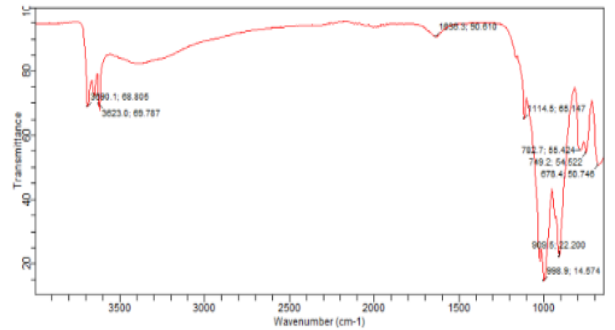

Fig. 3: FTIR of unmodified Iyi-Nsukka kaolin clay catalyst

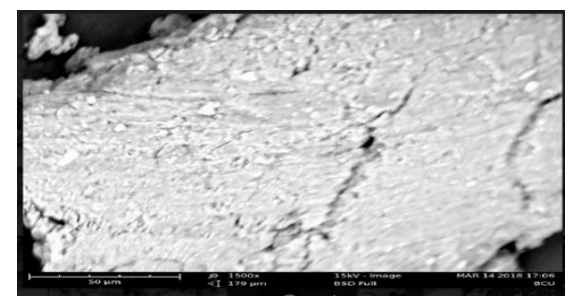

Fig. 5: SEM of UMIKCCat

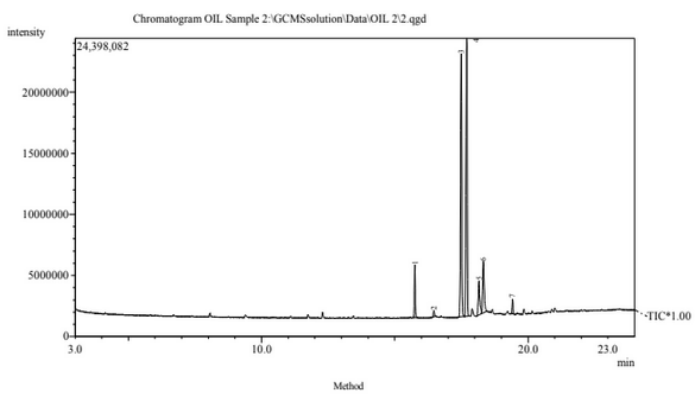

Fig. 7: GC-MS of gmelina seed oil

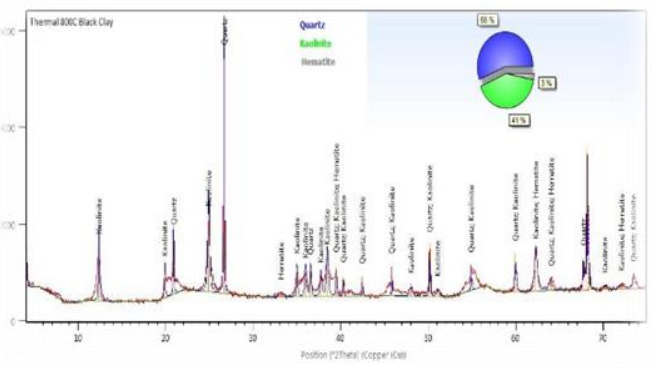

Fig. 2: XRD of thermally modified Iyi-Nsukka kaolin clay catalyst

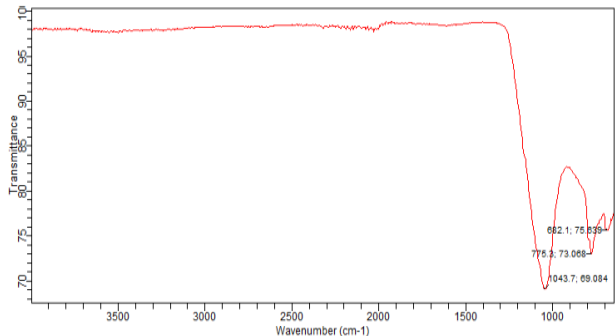

Fig. 4: FTIR of thermally modified Iyi-Nsukka kaolin clay catalyst

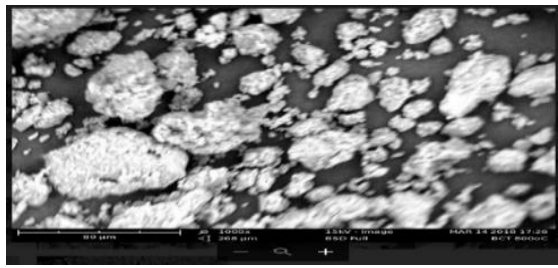

Fig. 6: SEM of TMIKCCat 800

Table 1: Elemental composition of unmodified and thermally modified Iyi-Nsukka kaolin clay catalysts

\begin{tabular}{ccl}
\hline Composition & UMIKCCat & TMIKCCat800 \\
\hline $\mathrm{Al}_{2} \mathrm{O}_{3}$ & 44.00 & 41.00 \\
$\mathrm{SiO}_{2}$ & 56.00 & 56.00 \\
$\mathrm{Fe}_{2} \mathrm{O}_{3}$ & 0.00 & 0.03 \\
$\mathrm{ZnO}$ & 0.00 & 0.00 \\
$\mathrm{TiO}_{2}$ & 0.00 & 0.00 \\
$\mathrm{~K}_{2} \mathrm{O}$ & 0.00 & 0.00 \\
$\mathrm{MgO}$ & 0.00 & 0.00 \\
$\mathrm{MnO}$ & 0.00 & 0.00 \\
$\mathrm{Na}_{2} \mathrm{O}$ & 0.00 & 0.00 \\
\hline
\end{tabular}

Table 2: Physiochemical properties of (UMIKCCat) and (TMIKCCat800)

\begin{tabular}{llll}
\hline Parameters & UMIKCCat & TMIKCCat800 & Range \\
\hline Moisture content (\%) & 0.04 & 0.02 & $\leq 0.05$ \\
Bulk Density $\left(\mathrm{g} \mathrm{cm}^{-3}\right)$ & 1.27 & 0.81 & $0.8-1.3$ \\
\hline
\end{tabular}

This publication is licensed under Creative Commons Attribution CC BY. 


\begin{tabular}{llll}
\hline Surface Area $\left(\mathrm{m}^{2} \mathrm{~g}^{-1}\right)$ & 710 & 778 & $670-800$ \\
Carbon (\%) & 3.49 & 1.11 & $1-6$ \\
Organic Matter (\%) & 10.35 & 5.19 & $1-15$ \\
Loss On Ignition (\%) & 17.80 & 29.40 & $13-30$ \\
Particle Density $\left(\mathrm{g} \mathrm{cm}^{-3)}\right.$ & 2.60 & 2.10 & $2.1-2.6$ \\
Total porosity (\%) & 51.36 & 57.75 & $51-58$ \\
\hline
\end{tabular}

Table 3: Properties of gmelina seed oil

\begin{tabular}{lll}
\hline Properties & $\begin{array}{c}\text { gmelina } \\
\text { seed oil }\end{array}$ & Range \\
\hline Specific gravity & 0.90 & $0.860-0.92$ \\
Kinematics viscosity $\left(\mathrm{mm}^{2} / \mathrm{s}\right)$ at $40^{\circ} \mathrm{C}$ & 7.75 & $1.9-6.0(\mathrm{ASTM} / \mathrm{D} 445)$ \\
& & \\
Free fatty acid $(\mathrm{mg} \mathrm{K} 0 \mathrm{H} / \mathrm{Kg})$ & 1.53 & $\leq 3(\mathrm{ASTM})$ \\
Iodine value $(\mathrm{g} / 100 \mathrm{~g})$ & 36.50 & $\leq 90(\mathrm{EN} 14111)$ \\
$\begin{array}{l}\text { Density }(\mathrm{g} / \mathrm{ml}) \\
\text { Saponification value }(\mathrm{mg} \mathrm{KOH} / \mathrm{Kg})\end{array}$ & 1.48 & \\
& 161.49 & $196-205$ \\
Refractive index & & \\
& 1.4985 & $1.447-1.490$ \\
Peroxide value Meq/Kg & & \\
Moisture content $(\%)$ & 0.91 & $0.1-5(\mathrm{ASTM})$ \\
\hline
\end{tabular}

Effect of process parameters on gmelina biodiesel yield using UMUKCCat and TMIKCCat800 catalysts.

The effect of catalyst concentration ranging from (1 to 6 wt.\%) expressed as weight percentage of the oil on the fatty acid methyl ester (FAME) yield is presented in Figure 8. Other parameters were kept constant: temperature $60^{\circ} \mathrm{C}$, reaction time 3hours, methanol/oil molar ratio 12:1, and agitation speed 300 rpm. The yield of methyl ester increased with increase in catalyst weight up to $3 \%$ wt. for all the catalysts with maximum methyl ester yields of $84 \%$ and $96 \%$ for UMUKCCat and TMIKCCat800 catalysts, respectively. The observed increase in yield of biodiesel is due to increase in exposed active catalyst sites. At excess catalyst concentration up to $6 \%$ wt. slight decrease in biodiesel yield was observed. The decrease in biodiesel yield is due to slight increase in the viscosity of the reactants mixture as high quantity of solid catalyst is introduced. This reduces the homogeneity and interaction between the reactants mixture and unreacted catalyst particles. The observation is similar to the findings of Yahya et al., (2019), Gollakota et al. (2019), Abukadra et al. (2019), Negm et al. (2018) and Li et al., (2018).

The effect of reaction time ranging from (1 to 6 hours) on the fatty acid methyl ester (FAME) yield were investigated. Other parameters were kept constant: temperature $60^{\circ} \mathrm{C}$, catalyst concentration $3 \mathrm{wt} . \%$, methanol/oil molar ratio 12:1, and agitation speed $300 \mathrm{rpm}$. It was found that biodiesel yield increased with increase in reaction time up to 3 hours for a maximum methyl ester yield of $84 \%$ and $96 \%$ for UMUKCCat and TMIKCCat800 catalysts, respectively. Further increase in time up to 6 hours resulted to slight decreased yield of biodiesel as shown in Figure 9. The slight decrease in biodiesel yield is due to slight dissolution of glycerol in the reactants mixture which resulted to slight increase in viscosity of reactants mixture. The observation is similar to the findings of Yahya et al., (2019), Gollakota et al. (2019), Abukadra et al. (2019), Negm et al. (2018) and Li et al., (2018).

This publication is licensed under Creative Commons Attribution CC BY.

http://dx.doi.org/10.29322/IJSRP.11.07.2021.p11590
The effect of temperature on the yield of biodiesel was investigated within the range of temperatures: 30 to $80^{\circ} \mathrm{C}$, while other parameters were kept constant: reaction time 3 hours, catalyst concentration $3 \mathrm{wt} \%$, methanol/oil molar ratio 12:1, and agitation speed $300 \mathrm{rpm}$. As shown in Figure 10, biodiesel yield increased with increase in reaction temperature up to $60^{\circ} \mathrm{C}$ with maximum methyl ester yield of $84 \%$ and $96 \%$ for UMUKCCat and TMIKCCat800 catalysts, respectively due to endothermic process of transesterification reaction. While at $70{ }^{\circ} \mathrm{C}$ decrease in biodiesel yield was observed. This is due to loss of methanol through vaporization since boiling point of methanol is $64.7^{\circ} \mathrm{C}$. The loss of methanol resulted to increase in viscosity of the reactants mixture due to reduction in methanol/oil molar ratio which inhibited the reaction and retards the formation of methyl ester. The observation is similar to the findings of Yahya et al., (2019), Gollakota et al. (2019), Abukadra et al. (2019), Negm et al. (2018) and Li et al.,(2018).

Effect of methanol/oil molar ratio on gmelina seed oil FAME yield was investigated within the range of $4: 1$ to $14: 1$ while other parameters were kept constant: reaction time 3 hours, catalyst concentration $3 \mathrm{wt} \%$, reaction temperature $60^{\circ} \mathrm{C}$, and agitation speed $300 \mathrm{rpm}$. The biodiesel yield increased with increase in methanol/oil molar ratio up to maximum ester yield which was obtained at a methanol oil molar ratio of 12:1. (See Figure 11). Methanol in sufficient ratio increases the solubility and homogeneity of the reactants mixture, enhance interaction of the reactants mixture which resulted to increase in biodiesel yield. The higher molar ratio shift the reaction in forward direction, reduces catalyst concentration in the reactants mixture, increase the cost of production and recovery of methanol. The observation is similar to the findings of Yahya et al., (2019), Gollakota et al. (2019), Abukadra et al. (2019), Negm et al. (2018) and Li et al.,(2018). The effect of agitation speed ranging from (100 to $600 \mathrm{rpm}$ ) on the FAME yield were investigated. Other parameters were kept constant: temperature $60^{\circ} \mathrm{C}$, catalyst concentration 3 wt. $\%$, methanol/oil molar ratio $12: 1$, and time 3 hours. The yield of 
biodiesel increased with increase in agitation speed up to maximum ester yield which was obtained at agitation speed of 300 rpm as shown in Figure 12. Further increase in agitation speed up to 600rpm resulted in slight decreased yield. The slight decreased yield is due to very high random dispersion of reactants mixture on the walls of the reactor as a result of excess agitation. The observation is similar to the findings of Yahya et al., (2019), Gollakota et al. (2019), Abukadra et al. (2019), Negm et al. (2018) and Li et al., (2018).

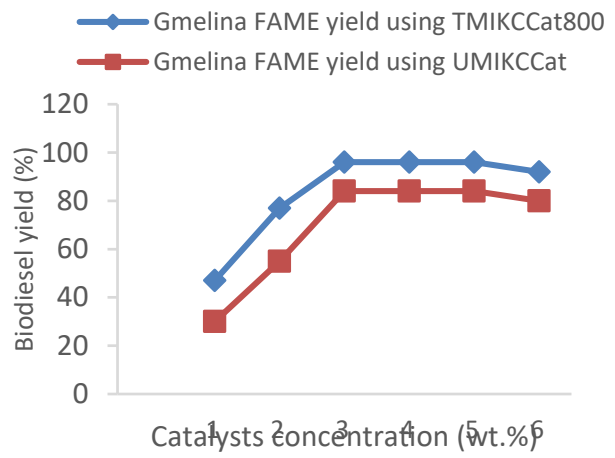

Figure 8: Effect of catalyst concentration on gmelina biodiesel yield

$\longrightarrow$ Gmelina FAME yield using TMIKCCat800

-Gmelina FAME yield using UMIKCCat

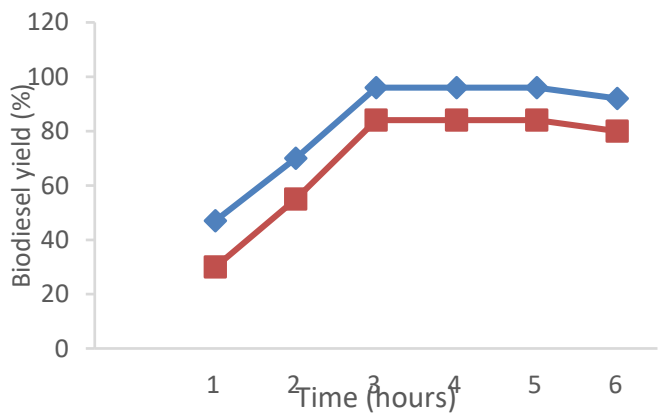

Figure 9: Effect of reaction time on gmelina biodiesel yield

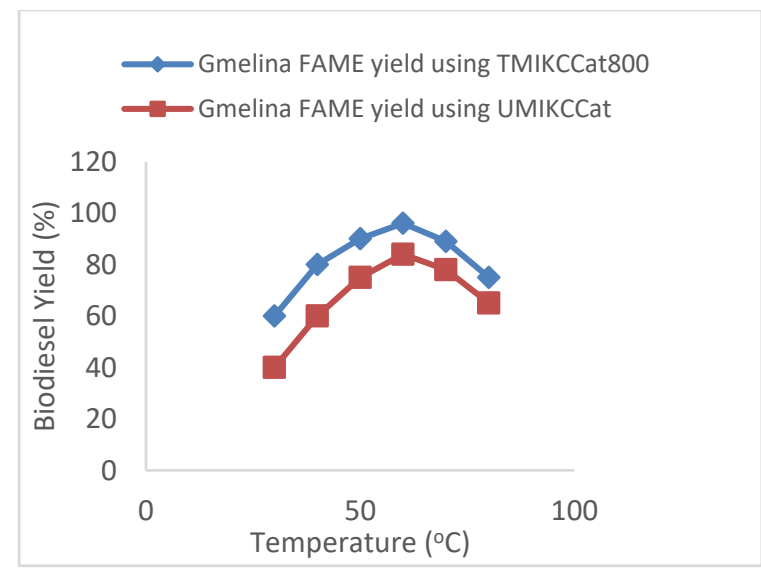




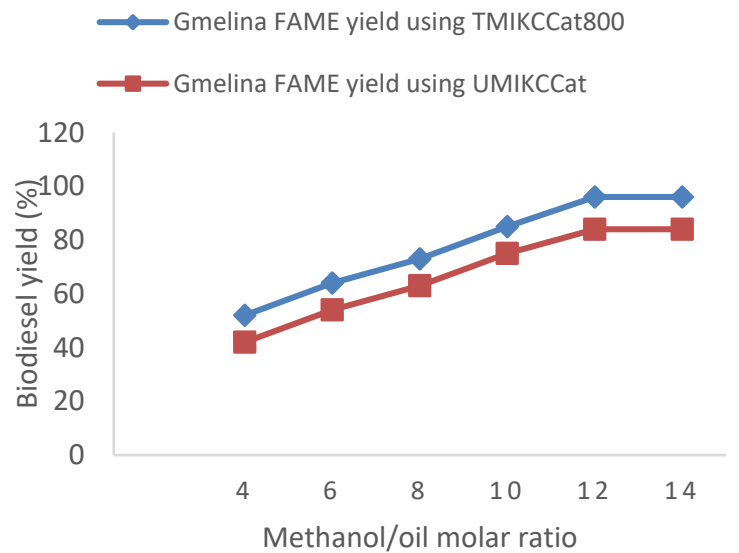

Figure 11: Effect of methanol/oil molar ratio on gmelina biodiesel yield

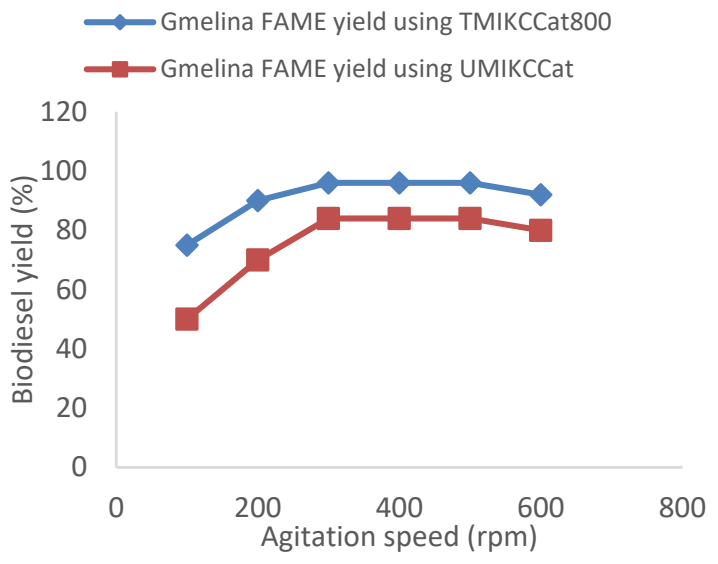

Figure 12: Effect of agitation speed on biodiesel yield

Quadratic regression equations that fitted the experimental data are given by Eq. (2) and Eq. (3) respectively for the yield of biodiesel using unmodified Iyi-Nsukka kaolin clay catalyst (UMIKCCat) and thermally modified Iyi-Nsukka kaolin clay catalyst (TMIKCCat800). Where $\mathrm{Y}$ is the response of the variables (percentage yield of biodiesel) and A-E are the coded values of the independent variables namely methanol/oil molar ratio, catalyst concentration, temperature, reaction time and agitation speed, respectively. The equations represent the quantitative effect of the factors (A, B, C, D, and E) upon the response (Y). Eq. (2) and Eq. (3) suggested that the yield of biodiesel has linear and quadratic effects on five variables studied. Coefficients with one factor represent the single effect of that particular factor while the coefficients with more than one factor represent the interaction between those factors. Positive sign in front of the terms indicate synergistic effect while negative sign indicates antagonistic effect of the factors.

$\mathrm{Y}=+74.06-0.5071 \mathrm{~A}+0.8713 \mathrm{~B}-1.64 \mathrm{C}-1.27 \mathrm{D}-0.6304 \mathrm{E}+1.39 \mathrm{AB}$ $+1.09 \mathrm{AC}-1.16 \mathrm{AD}+1.57 \mathrm{AE}-1.44 \mathrm{BC}+0.6294 \mathrm{BD}+0.9256 \mathrm{BE}-$

$$
\begin{array}{llll}
1.56 \mathrm{CD}-1.80 \mathrm{CE}+1.31 \mathrm{DE}-0.3199 \mathrm{~A}^{2}+1.68 \mathrm{~B}^{2}+0.3351 \mathrm{C}^{2} \\
+0.2114 \mathrm{D}^{2} .
\end{array}
$$

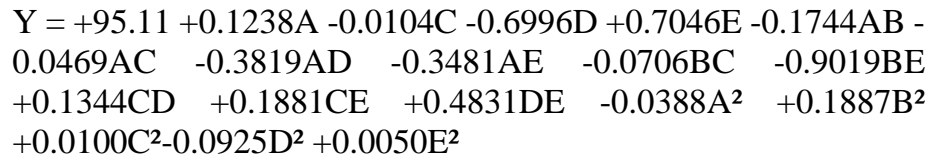

(3)

The adequacy of the proposed models for the yield of biodiesel using (UMIKCCat) and (TMIKCCat800) catalysts were tested using the Design Expert sequential model sum of squares and the model test statistics as shown in Table 4 and Table 5 respectively. From the statistical analysis, the regression coefficient $\left(R^{2}=0.9989\right)$, the Predicted $R^{2}$ of 0.9710 is in reasonable agreement with the Adjusted $\mathrm{R}^{2}$ of 0.9969 ; i.e. the difference is less than 0.2 for (UMIKCCat) catalyst also the regression coefficient $\left(R^{2}=0.9993\right.$, the Predicted $R^{2}$ of 0.9828 is in reasonable agreement with the Adjusted $\mathrm{R}^{2}$ of 0.9981 ; i.e. the difference is less than 0.2. for (TMIKCCat800) catalyst. 
Table 4 : Significance of regression coefficients of the yield of biodiesel produced from gmelina oil using unmodified IyiNsukka kaolin clay catalyst (UMIKCCat)

\begin{tabular}{|c|c|c|c|c|c|c|}
\hline Source & $\begin{array}{l}\text { Sum } \\
\text { Squares }\end{array}$ & $\begin{array}{l}\text { Degree of } \\
\text { Freedom }\end{array}$ & Mean Square & F-value & p-value & \\
\hline Model & 512.08 & 20 & 25.60 & 498.90 & $<0.0001$ & Significant \\
\hline A-Molar ratio & 6.17 & 1 & 6.17 & 120.25 & $<0.0001$ & \\
\hline B-Catalyst concentration & 18.22 & 1 & 18.22 & 354.98 & $<0.0001$ & \\
\hline C-Temperature & 64.78 & 1 & 64.78 & 1262.26 & $<0.0001$ & \\
\hline D-Reaction time & 38.58 & 1 & 38.58 & 751.79 & $<0.0001$ & \\
\hline E-Agitation Speed & 9.54 & 1 & 9.54 & 185.85 & 0.0021 & \\
\hline $\mathrm{AB}$ & 31.00 & 1 & 31.00 & 603.99 & 0.0031 & \\
\hline $\mathrm{AC}$ & 19.12 & 1 & 19.12 & 372.53 & $<0.0001$ & \\
\hline $\mathrm{AD}$ & 21.37 & 1 & 21.37 & 416.35 & 0.0004 & \\
\hline $\mathrm{AE}$ & 39.22 & 1 & 39.22 & 764.19 & $<0.0001$ & \\
\hline $\mathrm{BC}$ & 33.38 & 1 & 33.38 & 650.41 & 0.0011 & \\
\hline BD & 6.34 & 1 & 6.34 & 123.49 & 0.0019 & \\
\hline $\mathrm{BE}$ & 13.71 & 1 & 13.71 & 267.11 & $<0.0001$ & \\
\hline $\mathrm{CD}$ & 39.16 & 1 & 39.16 & 762.97 & 0.0012 & \\
\hline $\mathrm{CE}$ & 52.02 & 1 & 52.02 & 1013.63 & $<0.0001$ & \\
\hline DE & 27.38 & 1 & 27.38 & 533.49 & $<0.0001$ & \\
\hline$A^{2}$ & 3.00 & 1 & 3.00 & 58.49 & 0.0071 & \\
\hline $\mathrm{B}^{2}$ & 83.05 & 1 & 83.05 & 1618.22 & $<0.0001$ & \\
\hline $\mathrm{C}^{2}$ & 3.29 & 1 & 3.29 & 64.19 & 0.0061 & \\
\hline $\mathrm{D}^{2}$ & 1.31 & 1 & 1.31 & 25.53 & 0.0004 & \\
\hline$E^{2}$ & 0.0844 & 1 & 0.0844 & 1.64 & 0.2261 & \\
\hline
\end{tabular}

Table 5 : Significance of regression coefficients of the yield of biodiesel produced from gmelina seed oil using (TMIKCCat800) catalyst

\begin{tabular}{lllllll}
\hline Source & $\begin{array}{l}\text { Sum } \\
\text { Squares }\end{array}$ & $\begin{array}{l}\text { Degree of } \\
\text { freedom }\end{array}$ & $\begin{array}{l}\text { Mean } \\
\text { Square }\end{array}$ & F-value & p-value & \\
\hline Model & 121.69 & 20 & 6.08 & 822.26 & $<0.0001$ & Significant \\
A-Molar ratio & 0.08 & 1 & 0.08 & 11.04 & 0.0074 & \\
B-Catalyst & 0.0704 & 1 & 0.0704 & 9.52 & 0.0104 & \\
concentration & & & & & & \\
C-Temperature & 3.68 & 1 & 3.68 & 497.56 & $<0.0001$ & \\
D-Reaction time & 12.56 & 1 & 12.56 & 1697.03 & $<0.0001$ & \\
E-Agitation Speed & 29.35 & 1 & 29.35 & 3966.35 & $<0.0001$ \\
AB & 0.8100 & 1 & 0.8100 & 109.47 & $<0.0001$ & \\
AC & 1.37 & 1 & 1.37 & 185.00 & $<0.0001$ & \\
AD & 9.67 & 1 & 9.67 & 1307.14 & $<0.0001$ & \\
AE & 0.0729 & 1 & 0.0729 & 9.85 & 0.0094 & \\
BC & 0.6642 & 1 & 0.6642 & 89.77 & $<0.0001$ & \\
BD & 0.4830 & 1 & 0.4830 & 65.28 & $<0.0001$ & \\
BE & 24.26 & 1 & 24.26 & 3278.03 & $<0.0001$ & \\
CD & 4.43 & 1 & 4.43 & 598.83 & 0.0003 & \\
CE & 8.32 & 1 & 8.32 & 1124.84 & $<0.0001$ & \\
DE & 5.64 & 1 & 5.64 & 762.30 & $<0.0001$ & \\
$A^{2}$ & 6.96 & 1 & 6.96 & 940.37 & $<0.0001$ & \\
$B^{2}$ & 2.80 & 1 & 2.80 & 379.01 & 0.0012 & \\
$C^{2}$ & 2.65 & 1 & 2.65 & 357.87 & 0.0011 & \\
$D^{2}$ & 6.49 & 1 & 6.49 & 877.40 & $<0.0001$ & \\
E $^{2}$ & 0.1915 & 1 & 0.1915 & 25.88 & 0.0004 \\
\hline
\end{tabular}


Analysis of variance (ANOVA) for biodiesel yield using (UMIKCCat) and (TMIKCCat800) catalysts

The ANOVA results for the model terms are given in Table 4. ANOVA was applied to estimate the significance of the model at 5\% significance level. A model is considered significant if the $\mathrm{p}$-value (significance probability value) is less than 0.05 . From the $\mathrm{p}$-values presented in Tables 4 , it can be stated that all the linear terms $\mathrm{A}, \mathrm{B}, \mathrm{C}, \mathrm{D}$ and $\mathrm{E}$ interaction terms $\mathrm{AB}, \mathrm{AC}, \mathrm{AD}, \mathrm{AE}, \mathrm{BC}$, $\mathrm{BD}, \mathrm{BE}, \mathrm{CD}, \mathrm{CE}, \mathrm{DE}$ and quadratic terms $\mathrm{A}^{2}, \mathrm{~B}^{2}, \mathrm{C}^{2}$, and $\mathrm{D}^{2}$ were significant model terms wheras in table 5 , it can be stated that all the linear terms $\mathrm{A}, \mathrm{B}, \mathrm{C}, \mathrm{D}$ and $\mathrm{E}$, and interaction terms $\mathrm{AB}, \mathrm{AC}$, $\mathrm{AD}, \mathrm{AE}, \mathrm{BC}, \mathrm{BD}, \mathrm{BE}, \mathrm{CD}, \mathrm{CE}, \mathrm{DE}$ and quadratic terms $\mathrm{A}^{2}, \mathrm{~B}^{2}$, $\mathrm{D}^{2}$ and $\mathrm{E}^{2}$ were significant model terms.

\section{CONCLUSION}

Heterogeneous catalyzed transesterification of gmelina seed oil using unmodified and thermally modified Iyi-Nsukka kaolin clay as catalysts were investigated. Unmodified and thermally modified Iyi-Nsukka kaolin clay catalysts were prepared and characterized. Gmelina seed oil were extracted using soxhlet extraction method and characterised. The percentage oil extracted proved that gmelina seed is viable feedstock for biodiesel production. The methyl ester produced by transesterification of gmelina seed oil was within acceptable ASTM limits. Optimal process parameters were reaction time 3 hours, catalyst concentration 3 wt. $\%$, methanol/oil ratio $12 ; 1$, reaction temperature $60^{\circ} \mathrm{C}$ and agitation speed 300rpm with maximum methyl ester yield of $84 \%$ and $96 \%$ for UMIKCCat and TMIKCCat 800 catalysts, respectively. It was observed that thermally modified Iyi-Nsukka kaolin clay catalyst(TMIKCCat800) performed creditably over unmodified Iyi-Nsukka kaolin clay catalyst UMIKCCat, thermally modified kaolin clay catalyst show more disaggregation and disintegrations of structure of the particles of the clay sheet, increase in porous surface, increase in surface area as well as thermal transformation into metakaolinite upon thermal modification at $800^{\circ} \mathrm{C}$ whereas unmodified Iyi-Nsukka kaolin clay catalyst shows agglomeration of particles, interlocking and interpenetration of kaolinite particles with aggregate arrangement as revealed by their SEM micrograph. Sequel to the findings of this study thermally modified Iyi-Nsukka kaolin clay catalyst is recommended as cheap, non-corrosive, nontoxic, easy- separable, recyclable, and environmentally friendly catalysts for biodiesel production.

\section{REFERENCES}

[1] Abukhadra, M. R., Ibrahim, S. M., Yakout, S.M. \& Abdeltawab, A.A. (2019). Synthesis of $\mathrm{Na}$ +trapped bentonite / zeolite-p composite as a novel catalyst for effective production of biodiesel from palm oil; effect of ultrasonic irradiation and mechanism. Energy conversion and management journal, 196,739-750.

[2] Atta, A.Y., Ajayi, O.A. and Adefila, S.S. (2007) Synthesis of Faujasite Zeolite from Kankara Kaolin Clay. Journal of Applied Sciences Research, 3, 1017-1021. www.aensionline.com/jasr/jasr/2007/10172021

[3] Carrero, A., Vicente,G., Rodriguez, R., Linares, M. \& Del Peso, G. L. (2011). Hierarchical zeolites as catalysts for biodiesel production from nannochloropsis microalga oil. Catalysis today journal, 167:148-153.

This publication is licensed under Creative Commons Attribution CC BY

http://dx.doi.org/10.29322/IJSRP.11.07.2021.p11590
[4] Demirbas, A. (2009). Progress and recent trends in biodiesel fuels. Energy conversion and management journal, 50,14-34.

[5] Diko, M., Ekosse, G., \& Ogala, J. (2016). Fourier transform infrared spectroscopy and thermal analysis of kaolinitic clay from South Africa and Cameroon. Acta geodynamica et geromaterialia, 13, 2, 149.

[6] Gollakota, A.R.K., Volli, V. \& Shu, C.M. (2019) Transesterification of waste cooking oil using pyrolysis residue supported eggshell catalyst. Environmental science and technology journal, 661,316-25.

[7] Hosseini, M.R., Pazouki, M., Ranjbar, M. and Habibian, M. (2007) Bioleaching of Iron from Highly Contaminated Kaolin Clay by Aspergillus niger. Applied Clay Science, 37, 251-257. http://dx.doi.org/10.1016/j.clay.2007.01.0 10

[8] Lenarda, M., Storaro, L., Talona, A., Moretti, E. and Riello, P. (2007) Solid Acid Catalysts from Clays: Preparation of Mesoporous Catalysts by Chemical Activation of Metakaolin under Acid Conditions. Journal of Colloid and Interface Science, 311, 537-543. http://dx.doi.org/10.1016/j.jcis.2007.03.01 5

[9] Li, L., Yi, N., Wang, X., Lin, X. \& Zeng, T. (2018). QiuNovel triazolium-based ionic liquids as effective catalysts for transesterification of palm oil to biodiesel. Molecular liquid journal 249, 732-738

[10] Lussier, R.J. (1991) A Novel Clay-Based Catalytic MaterialPreparation and Properties. Journal of Catalysis, 129, 225- 237. http://dx.doi.org/10.1016/0021- 9517(91)90026-Z

[11] Negm, N. A., Zahran, M. K., Abd-Elshafy, M. R. \& Aiad, I. A. (2018). Transformation of jatropha oil to biofuel using transition metal salts as heterogeneous catalysts. Molecular liquid journal, 256, 16-21.

[12]

[13] Panda, B., Achyut, K., Mishraa, D.K., Mishrac, D. \& Singha, R. (2010). Colloids and surfaces A: Physicochemical engineering aspects. Applied clay science journal, 363, 98-10.

[14] Park, Y.M., Lee, D. W., Kim, D. K., Lee, J. S. \& L Lee, K. Y. (2008). The heterogeneous catalyst system for the continuous conversion of free fatty acids in used vegetable oils for the production of biodiesel. Catalysis today, 131: 238-243.

[15] Scorzelli, R.B., Bertolino, L.C., Luz, A.B., Duttine, $\quad$ M., Silva, F.A.N.G. \& Munayco, P. (2008) Spectroscopic Studies of Kaolin from Different Brazilian Regions. Clay Minerals, 43,129-135. http://dx.doi.org/10.1180/claymin.2008.04 3.1.10

[16] Singh, S. P. \& Singh, D. (2010). Biodiesel production through the use of different sources and characterization of oils and their esters as the substitute of diesel: A review. Renewable and sustainable energy journal, 14, 200-216.

[17] Yahya, N.Y., Ngadi, N., Wong, S. \& Hassan, O. (2019).

Transesterification of used cooking oil catalyzed by mesoporous calcium titanate: Kinetic and thermodynamic. Energy conversion and management journal, 164, 210-218.

\section{AUTHORS}

First Author - Odenigbo J.O, Department of Engineering Research Development and Production, Projects Development Institute (PRODA) Enugu, P.M.B.1609 Enugu, Nigeria.

Second Author - Chime T.O, Department of Chemical Engineering, Enugu State University of Science and Technology, P.M.B.01660 Enugu, Enugu state, Nigeria.

Third Author - Egbuna S.O, Department of Chemical Engineering, Enugu State University of Science and Technology, P.M.B.01660 Enugu, Enugu state, Nigeria.

Correspondence Author - +234803 899 3501; Email: judeodenigbo2@gmail.com. 
International Journal of Scientific and Research Publications, Volume 11, Issue 7, July 2021

This publication is licensed under Creative Commons Attribution CC BY. 